Volume. 3 Nomor. 1

Periode: Januari - Juni 2019; hal. 1-9

p-ISSN : 2580-1112; e-ISSN : 2655-6669

Copyrighr@2019

Jurnal Ilmiah Keperawatan Orthopedi

Penulis memiliki hak cipta atas artikel ini

journal homepage: https://ejournal.akperfatmawati.ac.id

(JIKO)

\title{
Meningkatkan Kooperatif Anak Melalui Permainan Ular Tangga
}

\author{
Ayuda Nia Agustina ${ }^{1}$, Mesia Christina Happy ${ }^{2}$, Nesri Aulina ${ }^{3}$ \\ Akademi Keperawatan Fatmawati, Jakarta Selatan
}

\begin{abstract}
Abstrak
Perkembangan pada anak usia prasekolah mengalami penurunan ketika anak mengalami sakit dan tak jarang mengharuskan mereka dirawat di rumah sakit (hospitalisasi). Anak-anak akan menjadi sangat tergantung dengan orang tua atau pengasuh, sehingga dapat mempengaruhi sikap kooperatif anak dan perkembangannya. Apabila tidak ditangani segera maka dapat menghambat perawatan selama di rumah sakit. Penelitian ini menganalisis penerapan terapi aktivitas bermain untuk meningkatkan kooperatif anak selama di rumah sakit. Desain yang digunakan adalah studi kasus. Terdapat empat kasus yang dibahas. Diagnosa keperawatan utama adalah risiko gangguan perkembangan anak. Intervensi utama yang diterapkan adalah permainan ular tangga. Hasil akhir penerapan terapi aktivitas bermain ular tangga menunjukkan bahwa terapi aktivitas bermain dapat meningkatkan kooperatif anak pra sekolah selama hospitalisasi. Hal ini ditunjukkan dengan adanya kontak mata keempat subjek saat berinteraksi dengan tenaga kesehatan, dapat bekerjasama dengan tenaga kesehatan dan subjek tidak sungkan bertanya terhadap prosedur yang dilakukan terhadapnya. Terapi aktivitas bermain berperan penting untuk memfasilitasi perkembangan anak, salah satunya adalah kooperatif selama dirawat di rumah sakit dan mempermudah proses pengobatan juga penyembuhan anak, sehingga pemberi an terapi aktivitas bermain perlu dilakukan secara konsisten oleh perawat dan keluarga agar proses pengobatan dan proses keperawatan dapat diberikan dengan optimal.
\end{abstract}

Kata Kunci: Anak Prasekolah, Hospitalisasi, Perkembangan, Terapi Bermain Ular Tangga

\begin{abstract}
The development's preschool children can be decrease when they have experiences of pain and hospitalized. Children will become very dependent on parents or caregivers, so that it can affect the child's cooperative attitude and development. If not treated immediately it can effect treatment while in hospital. This study analyzes the application of play therapy to improve children's cooperation while in hospital. The design used is a case study. There are four cases discussed. The main nursing diagnosis is the risk of developmental disorders in children. The main intervention applied was the snake and ladder game. The final results showed that play therapy could be increase the cooperatives of pre-school children during hospitalization. This is indicated by the eye contact of the four subjects when interacting with health workers, can work together with health workers and the subject does not hesitate to ask the procedures performed on them.
\end{abstract}

1,2,3 e-mail: ayudania@akperfatmawati.ac.id 
Play therapy plays an important role to facilitate children's development, one of which is cooperative during hospitalization and facilitates the treatment process as well as healing children, so that the provision of play therapy needs to be consistently by nurses and families so that the treatment process and nursing process can be optimally provided.

\section{Keywords: Preschool Children, Hospitalization, Development, Snake Ladder Play Therapy}

\section{Pendahuluan}

Berdasarkan data yang didapat dari Kementerian Pemberdayaan Perempuan dan Perlindungan Anak (2016), jumlah penduduk Indonesia mencapai 258 juta jiwa, sepertiga diantaranya $(32,24 \%)$ adalah anak-anak. Hal ini menunjukkan bahwa perubahan kesehatan pada anak akan sangat mempengaruhi angka kesehatan nasional. Angka kesakitan anak di Indonesia berdasarkan Survei Kesehatan Nasional (Susenas) tahun 2014 yang dikutip dalam Profil Anak Indonesia (2015), yaitu sebesar 15,26 \%. Angka kesakitan anak di daerah perdesaan sebesar $15,75 \%$, sementara angka kesakitan di daerah perkotaan sebesar $14,74 \%$. Melihat fenomena di atas angka kesakitan pada anak sangat tinggi, sehingga berdampak pada peningkatan jumlah anak yang dirawat di rumah sakit. Anak yang dirawat di rumah sakit akan mengalami masalah terhadap perubahan lingkungan, ketidaknyamanan selama berada di rumah sakit (hospitalisasi) yang dapat memberikan pengaruh terhadap pertumbuhan dan perkembangan anak.

Adapun dampak jangka pendek dari hospitalisasi yang tidak segera ditangani antara lain akan membuat anak melakukan penolakan terhadap tindakan perawatan dan pengobatan yang diberikan sehingga berpengaruh terhadap lamanya hari rawat, memperberat kondisi anak dan bahkan dapat menyebabkan kematian pada anak. Sedangkan dampak jangka panjangnya adalah akan mempengaruhi pada pertumbuhan dan perkembangan anak, antara lain adanya kesulitan dan kemampuan membaca yang buruk, memiliki gangguan bahasa dan perkembangan kognitif, serta menurunnya kemampuan intelektual dan sosial serta fungsi imun. Salah satu perkembangan anak dapat dicapai melalui bermain. Bagi anak, seluruh aktivitasnya adalah bermain yang juga mencakup bekerja, kesenangannya dan metode bagaimana mereka mengenal dunia. Ketika bermain, anak tidak hanya sekadar melompat, melempar atau berlari, tetapi mereka bermain dengan menggunakan seluruh emosi, perasaan dan pikirannya (Saputro \& Fazrin, 2017)

Berdasarkan pengamatan peneliti selama berada di rumah sakit, hampir semua anak yang dirawat mengalami dampak hospitalisasi, salah satunya anak usia sekolah dimana anak tersebut mengalami rasa cemas, takut terhadap perawat, sering menangis, rewel, tidak mau makan, tidak mau menggerakkan tangan yang terpasang infus, menolak untuk mobilisasi, bahkan menolak untuk dilakukan tindakan keperawatan. Anak yang mengalami kecemasan jika tidak dilakukan penanganan untuk mengatasi rasa cemasnya, akan mengakibatkan perilaku tidak kooperatif. Salah satunya anak akan melakukan penolakan terhadap tindakan perawatan dan pengobatan yang diberikan. Perilaku penolakan tersebut dapat berpengaruh terhadap lamanya hari rawat, memperberat kondisi anak, menghambat tumbuh kembang anak, serta dapat menyebabkan kematian pada anak. Melihat fenomena tersebut, maka pemberian terapi aktivitas bermain sangat diperlukan untuk memfasilitasi perkembangan anak pra sekolah selama mengalami hospitalisasi. Perawat merupakan salah satu pemberi pelayanan yang terdekat dengan pasien, sehingga 
peran perawat sangat penting dalam mengurangi masalah hospitalisasi.

Bermain dapat menjadi media terapi yang baik bagi anak-anak bermasalah. Selain berguna untuk mengembangkan potensi anak, bermain juga dapat dilakukan untuk meningkatkan sikap kooperatif anak. Bermain adalah pekerjaan atau aktivitas anak yang sangat penting. Melalui bermain akan semakin mengembangkan kemampuan dan keterampilan motorik anak, kemampuan kognitifnya. Melalui kontak dengan dunia nyata, menjadi eksis di lingkungannya, menjadi percaya diri, dan masih banyak lagi manfaat lainnya (Martin, 2008).

Beberapa penelitian terkait terapi aktivitas bermain yaitu penelitian yang dilakukan oleh Handayani dan Puspitasari (2009) memiliki adanya pengaruh terapi bermain terhadap tingkat kekooperatifan pada anak usia 3-5 tahun. Purwandari, dkk (2010) menyatakan bahwa terapi bermain berdampak terhadap penurunan kecemasan perpisahan pada anak yang mengalami hospitalisasi. Penelitian yang dilakukan oleh Nida Adilah dan Irman Somantri (2016) menyatakan bahwa terdapat perbedaan skor kecemasan pada usia toddler dan prasekolah setelah pemberian terapi mendongeng.

Penelitian Suryanti dan Yulistiani (2011) mengemukakan bahwa terdapat perbedaan antara tingkat kecemasan yang dialami anak sebelum dilakukan terapi bermain (mewarnai dan origami) dan sesudah dilakukan terapi bermain (mewarnai dan origami). Dalam penelitian tersebut dapat ditarik kesimpulan bahwa terapi bermain (mewarnai dan origami) dapat menurunkan tingkat kecemasan anak usia prasekolah, dari tingkat kecemasan sedang menjadi tingkat kecemasan ringan. Penelitian lain yang diungkapkan oleh Koukourikos, Tzeha, Pantelidou dan Tsaloglidou (2015) mengemukakan bahwa melalui bermain secara terapeutik dapat meningkatkan kesehatan fisik maupun emosional pada anak di rumah sakit.

\section{Metode}

Penelitian ini menggunakan desain studi kasus. Kasus yang diambil sebanyak 4. Tempat diadakan penelitian di ruang perawatan bedah dan penyakit infeksi anak (lantai 3 selatan dan 3 utara) RSUP Fatmawati. Penelitian dilakukan pada bulan April sampai dengan Juni 2018. Subjek dalam penelitian adalah anak pra sekolah, yaitu anak berumur 3-6 tahun yang memiliki masalah keperawatan risiko gangguan perkembangan.

Diagnosa medis dari keempat subjek adalah: Diare dengan dehidrasi berat, cedera kepala ringan, dan dua kasus prolong fever. Data didapatkan dari catatan medis, catatan keperawatan dan observasi subjek selama asuhan keperawatan diberikan. Intervensi utama yang diterapkan adalah permainan ular tangga. Etika penelitian yang diterapkan adalah memberikan manfaat kepada subjek, memberikan kebebasan anak dan atau orang tua untuk memilih berpartisipasi atau tidak dalam penelitian, menjaga privasi anak, mempertahankan kenyamanan dan bersikap adil.

\section{Hasil}

Kasus 1, Seorang anak laki-laki berinisial A berumur 6 tahun, dibawa ke IGD RSUP Fatmawati dengan keluhan utama mual muntah lebih dari 3 kali disertai darah dan sisa makanan, mengalami buang air besar (BAB) lebih dari 5 kali dengan konsistensi cair disertai lendir dan busa sebelum masuk rumah sakit. Diagnosis medis saat masuk yaitu diare dehidrasi berat. Ibu subjek berumur 44 tahun, beragama islam, suku bangsa jawa, pendidikan terakhir sarjana dan bekerja sebagai guru PAUD. Ayah subjek berumur 58 tahun, beragama Islam, suku bangsa betawi, pendidikan terakhir sarjana dan bekerja sebagai pegawai swasta. Sumber biaya JKN. 
Hasil pemeriksaan fisik, didapatkan data: kesadaran sadar penuh, berat badan anak saat ini 16 kilogram, berat badan sebelum sakit 17 kilogram, tinggi badan 104 sentimeter. tanda-tanda vital: frekuensi nadi: 90 kali per menit, frekuensi pernapasan: 20 kali per menit, suhu tubuh: $37,8{ }^{\circ} \mathrm{C}$. Hasil wawancara yang dilakukan dengan ibu subjek, yaitu selama di rumah sakit subjek selalu bermain handphone. Subjek selalu malu bila di dekati oleh petugas kesehatan dan selalu rewel bila dilakukan tindakan keperawatan. Selain itu, ibu merasa kesulitan untuk melarang subjek berhenti bermain handphone.

Masalah keperawatan yang teridentifikasi sebanyak empat, yaitu: Resiko kekurangan volume cairan, ketidakseimbangan nutrisi: Kurang dari kebutuhan tubuh berhubungan dengan penurunan asupan makanan, kerusakan integritas kulit, risiko gangguan perkembangan.

Intervensi yang diberikan yaitu mengevaluasi perkembangan anak usia prasekolah, memotivasi orangtua untuk mengajak anak bermain, memfasilitasi terapi aktivitas bermain, memberikan pujian terhadap orangtua yang mengajak anak bermain, meningkatkan latihan dengan menggunakan berbagai mainan di tempat tidur anak, memberikan distraksi setelah prosedur yang menyebabkan rasa takut, melibatkan orangtua pada saat dilakukannya tindakan keperawatan. Evaluasi asuhan keperawatan setelah lima hari yaitu : kekurangan volume cairan tidak terjadi, ketidakseimbangan nutrisi: Kurang dari kebutuhan tubuh belum teratasi, kerusakan integritas kulit teratasi gangguan perkembangan tidak terjadi.

Kasus 2, Seorang anak laki-laki berinisial $S$ berumur 6 tahun dibawa ke IGD RSUP Fatmawati dengan keadaan pingsan selama 4 jam. Sebelumnya subjek terjatuh dari sepeda dan terbentur trotoar. Diagnosis medis saat masuk yaitu cedera kepala ringan. Ibu subjek berumur 36 tahun, agama islam, suku bangsa jawa, pendidikan terakhir SLTA dan tidak bekerja. Ayah subjek berumur 40 tahun, agama islam, suku bangsa jawa, pendidikan terakhir SLTA, dan bekerja sebagai karyawan swasta. Sumber biaya yaitu BPJS.

Hasil pemeriksaan fisik didapatkan data kesadaran sadar penuh, berat badan anak saat ini adalah 16 kilogram, berat badan sebelum sakit 16 kilogram, tinggi badan 110 sentimeter. tanda-tanda vital: frekuensi nadi: 86 kali per menit, frekuensi pernapasan 22 kali per menit, suhu tubuh 38,5 ${ }^{\circ} \mathrm{C}$. Hasil wawancara yang dilakukan dengan ibu subjek yaitu anak tampak lebih diam bila diajak komunikasi. Anak tampak takut bila diajak komunikasi dengan petugas kesehatan, dan lebih banyak diam serta menunduk.

Berdasarkan data-data tersebut, teridentifikasi empat masalah keperawatan yaitu: Nyeri, risiko perdarahan, risiko infeksi dan risiko gangguan perkembangan. Intervensi yang diberikan yaitu mengevaluasi tingkat perkembangan anak usia prasekolah, memotivasi orangtua untuk mengajak anak bermain, memfasilitasi terapi aktivitas bermain, memberikan pujian terhadap orangtua yang mengajak anak bermain, meningkatkan latihan dengan menggunakan berbagai mainan di tempat tidur anak, memberikan distraksi setelah prosedur yang menyebabkan rasa takut, melibatkan orangtua pada saat dilakukannya tindakan keperawatan, kolaborasi pemberian terapi obat melalui oral piracetam 2 kali 1 tablet dan parenteral KaEn 1B 1000 cc per hari. Evaluasi masalah setelah 5 hari pemberian asuhan keperawatan yaitu: nyeri teratasi, perdarahan tidak terjadi, infeksi tidak terjadi, gangguan perkembangan tidak terjadi.

Kasus 3, seorang anak perempuan berinisial $\mathrm{S}$ berumur 5 tahun, dibawa ke RSUP Fatmawati dengan keluhan utama deman sejak 2 bulan yang lalu, deman semakin tinggi saat malam hari, dan 
mengalami diare sejak 5 hari yang lalu, terdapat keluhan nyeri pada seluruh tubuh terutama tangan dan kaki. Diagnosis medis yaitu Prolong Fever e.c Autoimun. Ibu anak berumur 36 tahun, beragama Islam, suku bangsa jawa, pendidikan terakhir tamat SMA, ibu rumah tangga. Ayah berumur 36 tahun, beragama Islam, suku bangsa jawa, pendidikan terakhir Diploma III, pekerjaan pegawai negri sipil. Sumber biaya BPJS.

Hasil pengkajian sebagai berikut: kesadaran sadar penuh, berat badan anak sekarang $22 \mathrm{~kg}$, berat badan sebelum sakit $24 \mathrm{~kg}$, frekuensi nadi: 110 kali per menit, frekuensi pernapasan: 24 kali per menit, suhu tubuh: $39,8{ }^{\circ} \mathrm{C}$. Konjungtiva pucat, membran mukosa kering, turgor kulit tidak elastis, waktu pengisian kapiler kurang dari 2 detik dan mendapatkan cairan infus. An. S mengeluh sakit jika kaki dan tangannya disentuh, anak rewel saat dilakukan tindakan, tampak cemas dan takut saat melihat perawat, kontak mata ada dengan perawat namun tidak bertahan lama. Hasil wawancara dengan ibu subjek didapatkan data bahwa subjek selama dirawat menjadi pendiam, selalu rewel saat dilakukan tindakan, cemas dan takut dengan perawat sehingga anak menjadi tidak kooperatif setiap dilakukan tindakan.

Teridentifikasi empat diagnosa keperawatan, yaitu: Ketidakefektifan perfusi jaringan perifer, kekurangan volume cairan, ketidakseimbangan nutrisi: kurang dari kebutuhan tubuh, dan risiko gangguan perkembangan anak. Intervensi yang diberikan yaitu mengevaluasi perkembangan dan sikap kooperatif subjek, memberikan sentuhan dan sering melakukan kontak mata, menjelaskan semua prosedur menggali apa yang akan dirasakan selama prosedur dilakukan, memfasilitasi bermain ular tangga bagi subjek dan keluarga, memberikan pujian kepada anak dan keluarga setelah terapi aktivitas bermain. Evaluasi keperawatan setelah lima hari perawatan yaitu: ketidakefektifan perfusi jaringan perifer belum teratasi, kekurangan volume cairan teratasi, ketidakseimbangan nutrisi: kurang dari kebutuhan tubuh belum teratasi dan gangguan perkembangan tidak terjadi.

Kasus 4, seorang anak laki-laki berumur 4 tahun dibawa ke RSUP Fatmawati dengan keluhan utama demam sejak 2 minggu yang lalu dan meningkat saat malam hari, batuk sejak 3 hari namun tidak ada produksi sputum. Diagnosis anak saat masuk yaitu prolong fever. Ibu berumur 30 tahun, beragama Islam, suku bangsa betawi, pendidikan terakhir sarjana dan ibu rumah tangga. Ayah subjek berumur 30 tahun, beragama Islam, suku bangsa betawi, pendidikan terakhir sarjana, pekerjaan pegawai negri sipil. Sumber biaya BPJS.

Hasil pengkajian didapatkan datadata: kesadaran sadar penuh, berat badan $20 \mathrm{~kg}$, tinggi badan $110 \mathrm{~cm}$. Frekuensi nadi 100 kali per menit, frekuensi pernapasan 23 kali per menit, suhu tubuh $38,0{ }^{\circ} \mathrm{C}$, anak rewel saat dilakukan tindakan, takut saat melihat perawat, kontak mata tidak ada dengan perawat, tidak peduli dengan lingkungan sekitar, dan sering bermain gadget telepon seluler. Hasil wawancara dengan ibu subjek, yaitu anak selama dirawat menjadi pendiam, rewel saat dilakukan tindakan, selalu bermain handphone karena merasa bosan, cemas dan takut dengan perawat, anak menjadi tidak kooperatif setiap dilakukan tindakan.

Berdasarkan data-data yang didapatkan, dirumuskan tiga diagnosa keperawatan, yaitu: ketidakefektifan perfusi jaringan perifer, ketidakseimbangan nutrisi: kurang dari kebutuhan tubuh dan risiko gangguan perkembangan. Intervensi yang diberikan yaitu mengevaluasi perkembangan anak, menjelaskan prosedur yang akan diberikan, memfasilitasi bermain ular tangga, memeriksa laboratorium darah lengkap. Setelah 5 hari pemberian intervensi, didapatkan bahwa ketidakefektifan perfusi jaringan perifer 
teratasi, ketidakseimbangan nutrisi: kurang dari kebutuhan tubuh belum teratasi, dan gangguan perkembangan tidak terjadi

\section{Pembahasan}

Pada keempat subjek tersebut saat diobservasi mengalami dampak hospitalisasi yang ditunjukkan pada reaksi keempat subjek selama mengalami hospitalisasi. Keempat subjek berada pada usia prasekolah yang memiliki ketergantungan dengan orangtua tinggi sehingga kerjasama dengan orangtua selama perawatan anak sangat dibutuhkan. Keluarga khususnya ibu adalah orang yang paling mengetahui apa yang dibutuhkan oleh anak.

Usia dikaitkan dengan pencapaian perkembangan kognitif anak menunjukkan bahwa anak usia prasekolah belum mampu menerima dan mempersepsikan penyakit dan pengalaman baru dengan lingkungan asing. Dalam penelitian (Tsai, 2007), semakin muda usia anak, kecemasan hospitalisasi akan semakin tinggi. Anak prasekolah lebih mungkin mengalami stres akibat perpisahan karena kemampuan kognitif anak yang terbatas untuk memahami hospitalisasi. Pada semua subjek, memperlihatkan reaksi selama hospitalisasi, yaitu, kontak mata kurang, rewel, memangis apabila didatangi petuugas kesehatan, dan tidak kooperatif.

Ketidakkooperatifan subjek selama hospitalisasi dipengaruhi berbagai macam stressor. Pada keempat kasus terpilih, yang menjadi penyebab stres subjek adalah status kesehatan, keberadaan tenaga kesehatan dan prosedur medis atau non medis yang didapatkan oleh subjek. prosedur medis yang didapatkan dapat menimbulkan nyeri. Susilaningrum, Nursalam dan Utami (2013) menjelaskan bahwa penyebab stres anak pra sekolah pada saat mengalami hospitalisasi antara lain cemas disebabkan perpisahan, kehilangan kontrol dan luka pada tubuh dan rasa sakit (nyeri).

Diagnosa keperawatan yang ada pada setiap kasus terpilih yaitu risiko gangguan perkembangan berhubungan dengan kecemasan, hospitalisasi. Diagnosa ini sesuai dengan teori yang diungkapkan oleh Susilaningrum, Nursalam dan Utami (2013).

Pelaksanaan keperawatan mengacu pada rencana tindakan keperawatan, bertujuan agar pasien mempunyai kemampuan kognitif (mengetahui, memahami, dan menyadari), afektif (mau dan bersedia), dan psikomotor (memperagakan, menyadari). Pelaksanaan keperawatan dilakukan sesuai dengan perencanaan keperawatan dan disesuaikan dengan keadaan dan kondisi pasien.

Permainan ular tangga adalah permainan yang menggunakan dadu untuk menentukan berapa langkah yang harus dijalani bidak. Permainan ini masuk dalam kategori "board game" atau permainan papan sejenis dengan permainan monopoli, halma, ludo, dan sebagainya. Papan berupa gambar petakpetak yang terdiri dari 10 baris dan 10 kolom dengan nomor 1-100, serta bergambar ular dan tangga (Husna, 2009).

Alasan menggunakan permainan ular tangga bertujuan untuk memperjelas konsep, pola, dan urutan bilangan, mampu memuaskan rasa ingin tahu, membayangkan, dan menerjemahkan pengalaman bermain tersebut menjadi sesuatu yang bermakna bagi anak, serta mengembangkan kemampuan kognitif. Di samping itu, teknik permainan ular tangga dapat mengurangi dampak hospitalisasi dan kecemasan sehingga didiharapkan perkembangan anak pada askpek sikap kooperatif dapat meningkat. Permainan ular tangga diberikan dengan durasi 15 menit di setiap sesinya. Dalam sehari permainan ular tangga dapat diberikan 23 sesi. 
Menurut Deslidel, Hasan, Hevrialni dan Sartika (2011), tujuan bermain di rumah sakit adalah untuk melanjutkan pertumbuhan dan perkembangan secara optimal, mengekspresikan perasaan, keinginan dan fantasi serta ide-idenya, mengembangkan kreativitas anak sehingga anak dapat beradaptasi lebih efektif terhadap stres. Adapun manfaat dari bermain menurut Wong (2009) adalah memberikan sarana untuk melepaskan diri dari ketegangan dan stres yang dihadapi di lingkungan.

Kooperatif berarti bersifat kerja sama, bersedia membantu. Kooperatif adalah sikap yang menunjukkan kerja sama, tidak melakukan penentangan terhadap suatu sikap individu maupun golongan tertentu. Dalam hal ini kerja sama yang dimaksud adalah kerja sama yang ditunjukkan anak selama menjalani perawatan di rumah sakit (KBBI, 2013). Sikap kooperatif pada anak sangat dipengaruhi oleh adanya faktor dukungan keluarga, yakni kehadiran keluarga di rumah sakit, keterlibatan keluarga dalam pemberian asuhan keperawatan dan hubungan keluarga dengan perawat dan tim kesehatan lain. Peran perawat dalam mengoptimalkan tingkat kooperatif anak, salah satunya adalah dengan menyusun perencanaan keperawatan terapi aktivitas bermain untuk mengurangi dampak hospitalisasi

Selama penelitian dilaksanakan, peneliti mengobservasi sikap dan perilaku subjek sebelum dan setelah diberikan intervensi terapi aktivitas bermain setiap hari selama 5 hari. Hari ke-5 pemberian intervensi, keempat subjek menunjukkan adanya kontak mata dengan tenaga kesehatan yang datang ke tempat tidurmya, tidak lagi rewel, subjek menyebutkan namanya, subjek mau diajak bermain, menyatakan senang setelah bermain, tidak menangis apabila ditinggal ibu, dapat mengajukan bertanya tentang prosedur yang akan diberikan, frekuensi berinteraksi dengan handphone pun sudah minimal, hanya $1-2 x$ per hari degan durasi 15 menit.

Reaksi anak setelah diberikan terapi bermain, sejalan dengan hasil penelitian Levy dan Alan (2009) yang mengemukakan bahwa melalui bermain secara terapeutik dapat meningkatkan kesehatan fisik maupun emosional pada anak di rumah sakit. Penelitian Ningrum dan Nasrudin (2015) menyatakan bahwa ada pengaruh bermain kolase kartun terhadap tingkat kooperatif anak prasekolah selama prosedur nebulizer di Rumah Sakit Airlangga. Wiguna, Kusumaningsih dan Sumarni (2015) dalam penelitiannya juga mengungkapkan bahwa terdapat pengaruh penggunaan elastic bandage bermotif (stiker) terhadap tingkat kooperatif anak usia prasekolah selama prosedur injeksi IV preset di Rumah Sakit Umum Daerah Klungkung. Begitu pula dengan Handayani dan Puspitasari (2010) dalam penelitiannya mengatakan bahwa ada pengaruh terapi bermain terhadap tingkat kooperatif pada anak usia 3-5 tahun di Ruang CB2 Anak Rumah Sakit Panti Rapih Yogyakarta.

\section{Kesimpulan}

Terapi aktivitas bermain menggunakan ular tangga dapat menjadi pilihan intervensi untuk mengatasi masalah kecemasan, dampak hospitalisasi dan risiko gangguan perkembangan pada anak pra sekolah, namun dibutuhkan komitmen oleh perawat agar dapat diterapkan secara rutin dan terstruktur sehingga dapat memberikan manfaat.

\section{Ucapan Terima Kasih}

Akademi Keperawatan Fatmawati yang telah membantu pembiayaan dan pendanaan penelitian. Pihak RSUP Fatmawati tempat penelitian dilaksanakan terutama staf lantai 3 utara (ruang ruang perawatan bedah) dan 3 selatan (ruang perawatan penyakit infeksi) yang telah memberikan banyak bantuan terlibat penelitian dan seluruh perawat yang 
bersedia ikut berpartisipasi sehingga penelitian ini dapat selesai, serta keluarga yang senantiasa memberikan dukungan secara materil dan non materi.

\section{Daftar Pustaka}

A'diilah, N., \& Somantri, I. (2016). Efektifitas terapi mendongeng terhadap kecemasan anak usia toddler dan prasekolah saat tindakan keperawatan. Jurnal Keperawatan Padjajaran, 4(3), 248-254. DOI: https://doi.org/10.24198/jkp.v4i3.28 7.g137.

Deslidel, Hasan, Z., Hevrialni, R., \& Sartika, Y. (2011). Buku ajar asuhan neonatus, bayi dan balita. Jakarta: EGC.

Handayani, R., \& Puspitasari. (2009). Pengaruh terapi bermain terhadap tingkat kooperatif selama menjalani perawatan pada anak usia prasekolah (3-5 tahun) di Rumah Sakit Panti Rapih Yogyakarta. Jurnal Kesehatan Surya Medika 1(1), 4-7. Diunduh dari https://www.scribd.com/document/3 58496040.

Handayani, R., \& Puspitasari, N. (2010). Pengaruh terapi bermain terhadap tingkat kooperatif selama menjalani perawatan pada anak usia pra sekolah (3-5 tahun) di rumah sakit panti rapih Yogyakarta. Jurnal Kesehatan Surya Medika Yogyakarta, 1(1), 1-17. Diunduh dari http://www.academia.edu/ download/36654275/7.pdf.

Kementerian Pemberdayaan Perempuan dan Perlindungan Anak. (2016). Profil anak Indonesia tahun 2017. Jakarta: Kementerian Pemberdayaan Perempuan dan Perlindungan Anak. Diakses dari https://www.kemenpppa.go.id/index .php/page/read/25/1587/profil-anakindonesia-tahun-2017.

Koukourikos, K., Tzeha, L., Pantelidou, P., \& Tsaloglidou, A. (2015). The importance of play during hospitalization of children. Proffesional Paper, 27(6), 438-441. Diunduh dari https://www.ncbi.nlm.nih.gov/pmc/ articles/PMC4733554/.

Levy, Alan J. (2009). Neurobiology and the Therapeutic Action of Psychoanalytic Play Therapy with Children. Clinical Social Work Journal, 39(1), 50-60. doi: 10.1007/s10615-009-0229-x

Martin. (2008).Bermain Sebagai Media Terapi, Diambil pada tanggal 20Februari 2008, Available:http://www.tabloidnakita.com.

M. Husna, A. (2009). 100+ Permainan tradisional indonesia untuk kreativitas, ketangkasan, dan keakraban. Yogyakarta: Penerbit Andi.

Ningrum, U., \& Nasrudin. (2015). Pengaruh terapi bermain kolase kartun terhadap tingkat kooperatif anak usia pra sekolah selama prosedur nebuleser di rumah sakit airlangga Jombang. Jurnal Edu Health, 5(1), 41-50. Diunduh dari http://www.journal.unipdu.ac.id/ind ex.php/eduhealth/article/viewFile/4 70/417.

Nursalam, Susilaningrum, R., \& Utami, S.(2013). Asuhan Keperawatan Bayi dan Anak .Jakarta: Salemba Medika

Pusat Bahasa Depdiknas. (2013). Kamus Besar Bahasa Indonesia. Jakarta: Balai Pustaka.

Purwandari, H., Mulyono W. A., \& Sucipto U. (2010). Terapi bermain untuk menurunkan kecemasan perpisahan pada anak prasekolah yang mengalami hospitalisasi. Jurnal Keperawatan Profesional Indonesia, 1(2) 52-59. Diunduh dari http://download.portalgaruda.org/art icle.

Saputro, H., \& Fazrin, I. (2017). Anak sakit wajib bermain di rumah sakit: penerapan terapi bermain anak 
sakit, proses, manfaat dan pelaksanaannya. Ponorogo: FORIKES.

Suryanti, S., \& Yulistiani, M. (2011). Pengaruh terapi bermain mewarnai dan origami terhadap tingkat kecemasan sebagai efek hospitalisasi pada anak usia pra sekolah di RSUD dr. R. Goetheng Tarunadibrata Purbalingga. Jurnal Kesehatan Samodra Ilmu, 3, 73-80. Diunduh dari http://fmipa.umri.ac.id/wpcontent/uploads/2016/04/jurnaledisi-VI.pdf\#page $=3$.

Susenas. (2010). Angka kesakitan anak di Indonesia. Jakarta: Badan Pusat Statistik.
Tsai, C (2007). The Effect of animal assisted therapy on children`s stress during hospitalization. Doctoral Distertasi of phylosopy. Univercity of marylan, school of nursing

Wiguna, I., Kusumaningsih, F., \& Sumarni, M. (2015). Pengaruh penggunaan elastic bandage bermotif (stiker) terhadap tingkat kooperatif anak usia pra sekolah selama prosedur injeksi iv (intra vena) preset. Community of Publishing in Nursing, 3(3), 45-53. Diunduh dari https://ojs.unud.ac.id/index.php/copi ng/ article/ view/14052.

Wong, D. (2009). Buku ajar keperawatan pediatrik. Jakarta: EGC 